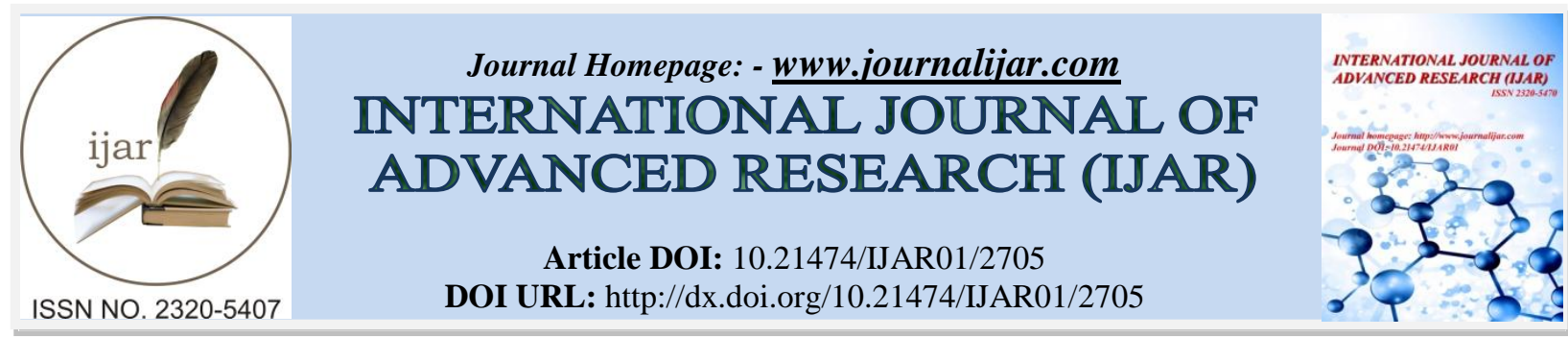

RESEARCH ARTICLE

\title{
APPRAISAL OF BLOOD BORNE INFECTION AS AN OCCUPATIONAL RISK AMONG DENTISTS IN THE DENTAL HEALTH FACILITIES.
}

Mohammed Abdulaziz Mirza Akram.

College of Density,Taibah University of Medina.

\section{Manuscript Info}

Manuscript History

Received: 31 October 2016

Final Accepted: 01 December 2016

Published: December 2016

Key words:-

Bloodborne Diseases, Dentists, El-

Madinah El-Munawarah, Knowledge,

Prevent.

\section{Abstract}

Introduction: Dental practitioners as other healthcare workers deal with a identified risk of occupational exposure to blood-borne pathogens like the Human Immunodeficiency Virus (HIV), the hepatitis B virus (HBV), and the hepatitis $\mathrm{C}$ virus (HCV).

Aim: To find out the extent of awareness of dentists in El-Madinah ElMunawarah to the occupational risk of blood borne infection.

Material and Method: A cross-sectional analytic study using a selfadministered questionnaire will be distributed to (174) dentists in the various centres and hospitals in El-Madinah El-Munawarah. The questionnaire questions will be related to participants' nationality, age, and gender, where they are working in (private or governmental) and their awareness of blood-borne infection.

Results: The results based on analysis of collected data show dentists have the knowledge about blood-borne disease had a good percentage of knowledge.

About the potential routes of blood-borne infections in the dental setting, more than $70 \%$ of dentists have enough knowledge to protect themselves.

Conclusion: Safer work practices and instrumentation and continued worker education, with particular reared to post-treatment handling of sharp dental instruments and equipment, may reduce occupational blood exposure among dentist.

Copy Right, IJAR, 2016,. All rights reserved.

\section{Introduction:-}

Dental practitioners as other healthcare workers deal with a identified risk of occupational exposure to blood-borne pathogens like the Human Immunodeficiency Virus (HIV), the hepatitis B virus (HBV), and the hepatitis $\mathrm{C}$ virus (HCV).[1]

In dentistry, sharps injuries occur because of a small operating field, frequent patient movement, and the variety of sharp instruments used in dental procedure.[2] The risk of exposure to blood-borne infections during the clinical dental training, consequences of non-reporting, and lack of appropriate follow-up or even infection should constantly be evaluated by dental institutions.[2]

The risk of HIV transmissions to healthcare workers approximately range from 0.2 to $0.3 \%$ for parenteral exposures and $0.1 \%$ or less for mucosal exposures.[3] A report published by the Centers for Disease control and Prevention 
(CDC) studied the 208 dental exposures (percutaneous, mucous membrane, and prolonged skin exposures) communicated to the CDC from 1995 to 2001, 13\% had HIV-positive source patients and did not lead to a seroconversion (75\% of exposed individuals took the three-drug PEP regimen for variable lengths of time).[4]

Percutaneous exposure to HBV containing transmission risk about $2 \%$ for $\mathrm{HBeAg}$-negative and $30 \%$ for $\mathrm{HBeAg}-$ positive blood.[2] Despite reducing the risk for HBV transmission among healthcare workers by effective HBV vaccination programs, measuring of anti-HBs antibody response after $\mathrm{HBV}$ vaccination is essential for all vaccinated individuals with high-risk professions.[1, 2]

HCV transmission risk is $1.8 \%$ and is the most serious viral hepatitis infection because of its ability to produce chronic infection in as many as $85 \%$ of those infected.[5, 6] The U.S. Public Health Service recommendations for $\mathrm{HCV}$ exposures implicate precise follow-up of the exposed practitioners and referral for appropriate therapy if an infection occurs.[7]

Dentists can acquire BBV infections through exposure to patient blood during procedures. Dentists can transmit BBV infection when patients are exposed to the blood of the dentist; these exposures are more frequent than many dentists appreciate. In 1986, US dentists reported an average of one percutaneous injury per month [8].

In 1991, the main causes of percutaneous injury in dentistry were burs (31\%), syringe needles (30\%), sharp instruments including laboratory knives (21\%), and orthodontic wire (6\%) [9].

Fortunately, the frequency of percutaneous injury by dentists appears to have declined to about 0.28 injuries per month, or 3.35 per year [10], likely as a result of Standard Precautions. However, it is probable that many percutaneous injuries are unrecognized since surgeons perceive only 30-66\% of glove perforations $[11,12]$.

Patients are exposed to the dentist's or surgeon's blood when the sharp object that caused the injury re-contacts the patient; one study reported that this happened in $32 \%$ of sharp object injuries to surgeons [13].

It is clear that there is a very real risk of viral transmission in the dental office. There is evidence of transmission of $\mathrm{HBV}, \mathrm{HIV}$, and HCV in the dental clinic and those who are not immune to HBV are particularly at risk. Also, there are clear indications that the frequency of exposures to blood among dentists needs to be reduced to minimize the risk of occupationally acquired blood-borne infections. [13].

\section{Study objectives:-}

- To evaluate the extent of awareness of dentists in El-Madinah El-Munawarah to the occupational risk of blood borne infection.

\section{Study design:-}

A cross-sectional analytic study using a self-administered questionnaire will be distributed to dentists in the various centres and hospitals in El-Madinah El-Munawarah.

A self-administered anonymous questionnaire WAS designed to assess the knowledge, attitude, and practices of dentists while there are in dental clinics along with corresponding demographic variables. Questionnaire questions were carefully selected from relevant published reports in international journals. The questionnaire questions WERE related to THE participants' nationality, age, and gender, where they are working in (private or governmental) and their awareness of blood-borne infection.

Dentists working in both private and governmental centres in El-Madinah El-Munawarah WERE invited to participate after they have been informed Verbally about the importance of the study. A waiver of documentation form will be requested based on the nature of the survey tool that is a self-administered questionnaire

\section{Sample size:-}

The sample was calculated using Raosoft sample size calculator [14]. For an approximately a population size 412 (information was provided by from PABMDC), assuming a response distribution of 50\%, Confidence level of $95 \%$, accepted margin of error $5 \%$. The sample size of the study population is 210 subjects. 
Patient selection:-

Inclusion criteria:-

Inclusion criteria for sampling will be in all dentists who are currently work in El-Madinah El-Munawarah.

\section{Exclusion criteria:-}

Non-dentists.

Ethical clearance form:-

The study protocol described herein will be obtained from the College Research Ethics Committee (REC), and a written informed consent from each patient will be achieved according to the Taibah University Research Ethics Committee (TUREC). The study will conform to the principles outlined in the Declaration of Helsinki.

\section{Statistical Analysis:-}

Data entry and analyzes of results will be done using the Statistical Package for Social Sciences (SPSS) ver 21 for Windows software1. Descriptive statistics such as mean and standard deviation (SD) for continuous variables and frequency and percentage for categorical variables will be determined. Inferential statistics will then be followed using parametric and non-parametric test for univariate analysis followed by multivariate analysis using logistic regression. The level of significance was set at $\mathrm{p}<0.05$.

\section{Results:-}

Dental practitioners as other healthcare workers deal with a identified risk of occupational exposure to blood-borne pathogens like the Human Immunodeficiency Virus (HIV), the hepatitis B virus (HBV), and the hepatitis C virus (HCV).

In dentistry, sharps injuries occur because of a small operating field, frequent patient movement, and the variety of sharp instruments used in dental procedure. Moreover, to find out the extent of awareness of dentists in El-Madinah El-Munawarah to the occupational risk of blood borne infection.This cross-sectional analytic study is for comparison of knowledge of dentist about blood-borne diseases.

A total of 174 participants from both genders in El-Madinah El-Munawarah particpated in the study

\section{Personnel data:-}

The sex distribution of the participants were $51.7 \%$ male and $48.3 \%$ female (Table1).

The majority of the participants were aged between 31-35 years old (Table2).

Educational status $48.3 \%$ of participants had Bachelor degree in dentistry, 35.1\% Masters degree and 16.7\% Ph.D. degree. (Figure1) .

Half of the Participants they graduate and practicing since 1-5 years (Table 3,4).

Participants are working in ministry of health about $36 \%, 31.4 \%$ in private clinic $28.5 \%$ university college $4.1 \%$ in other places (Figure2).

Participants had a needle stick or sharps injury within the last year 61.5\% (Table5 ). 67.6\% They report the incident (Table5).

If they injured they washed the site with water and soap about 34.8\%, 39.1\% Washed the site with an antiseptic solution (e.g. Alcohol, etc..), Only squeezed the blood out around $21 \%$ and whom did nothing about 5.1\% (Table6).

Prevention measures:-

Most of the participants recapped the used needles (Table 5). 
The most Technique of recapped was one handed method (Table 7). The most way to disposed off the used needles is In a sharps container (safety boxes) (Table 8).

94.3\% of the participants are washing their hands between each patient (Table 5).

During practicing $97.7 \%$ they wear gloves, $96.6 \%$ are wearing mask, $38.5 \%$ they used protective eye and $72.4 \%$ wearing gowns, lab coats (Table 9).

Information measures:-

General knowledge of participants about blood borne diseases (HBV, HCV, HIV) (Table 10).

Information about the Potential routes of blood-borne infections in the dental setting. (Table11)

Table 1:- The gender of the Participants.

\begin{tabular}{|l|l|l|}
\hline & Frequency & Percent \\
\hline Male & 90 & 51.7 \\
\hline Female & 84 & 48.3 \\
\hline Total & 174 & 100 \\
\hline
\end{tabular}

Table 2:- The age of the participants.

\begin{tabular}{|l|l|l|}
\hline & Frequency & Percent \\
\hline $25-30$ & 55 & 31.6 \\
\hline $31-35$ & 70 & 40.2 \\
\hline $36-40$ & 28 & 16.1 \\
\hline$\geq 40$ & 21 & 12.1 \\
\hline Total & 174 & 100 \\
\hline
\end{tabular}

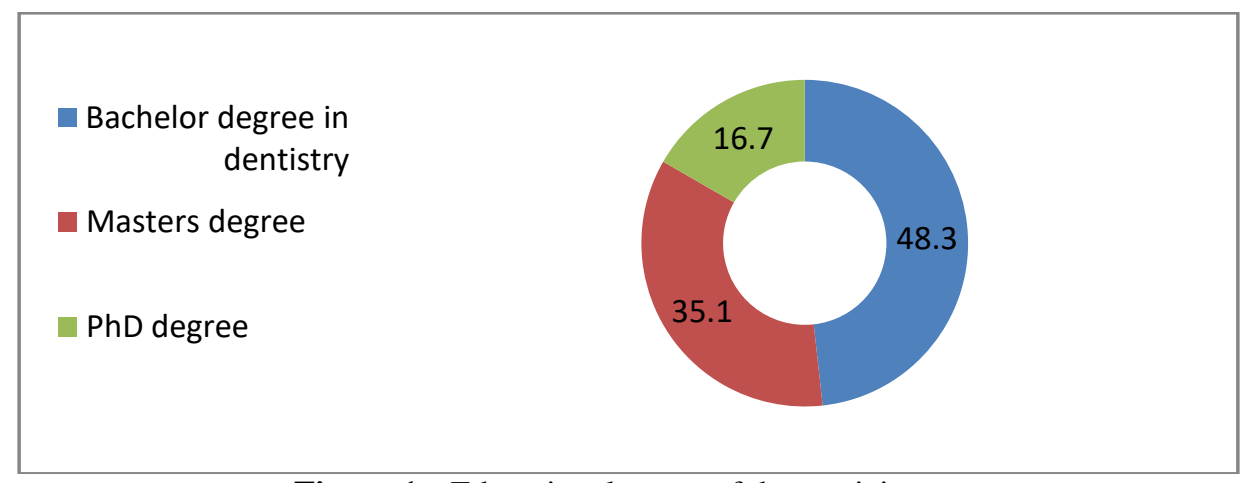

Figure 1:- Educational status of the participants

Table 3:- Years since graduation

\begin{tabular}{|l|l|l|}
\hline & Frequency & Percent \\
\hline $1-5$ & 88 & 50.6 \\
\hline $6-10$ & 38 & 21.8 \\
\hline $11-15$ & 27 & 15.5 \\
\hline $16-20$ & 14 & 8 \\
\hline$\geq 20$ & 7 & 4 \\
\hline Total & 174 & 100 \\
\hline
\end{tabular}

Table 4:- Years since practicing.

\begin{tabular}{|c|c|c|}
\hline & Frequency & Percent \\
\hline $1-5$ & 85 & 48.9 \\
\hline $6-10$ & 27 & 15.5 \\
\hline $11-15$ & 30 & 17.2 \\
\hline $16-20$ & 24 & 13.8 \\
\hline
\end{tabular}




\begin{tabular}{|c|c|c|}
\hline$\geq 20$ & 8 & 4.6 \\
\hline Total & 174 & 100 \\
\hline
\end{tabular}

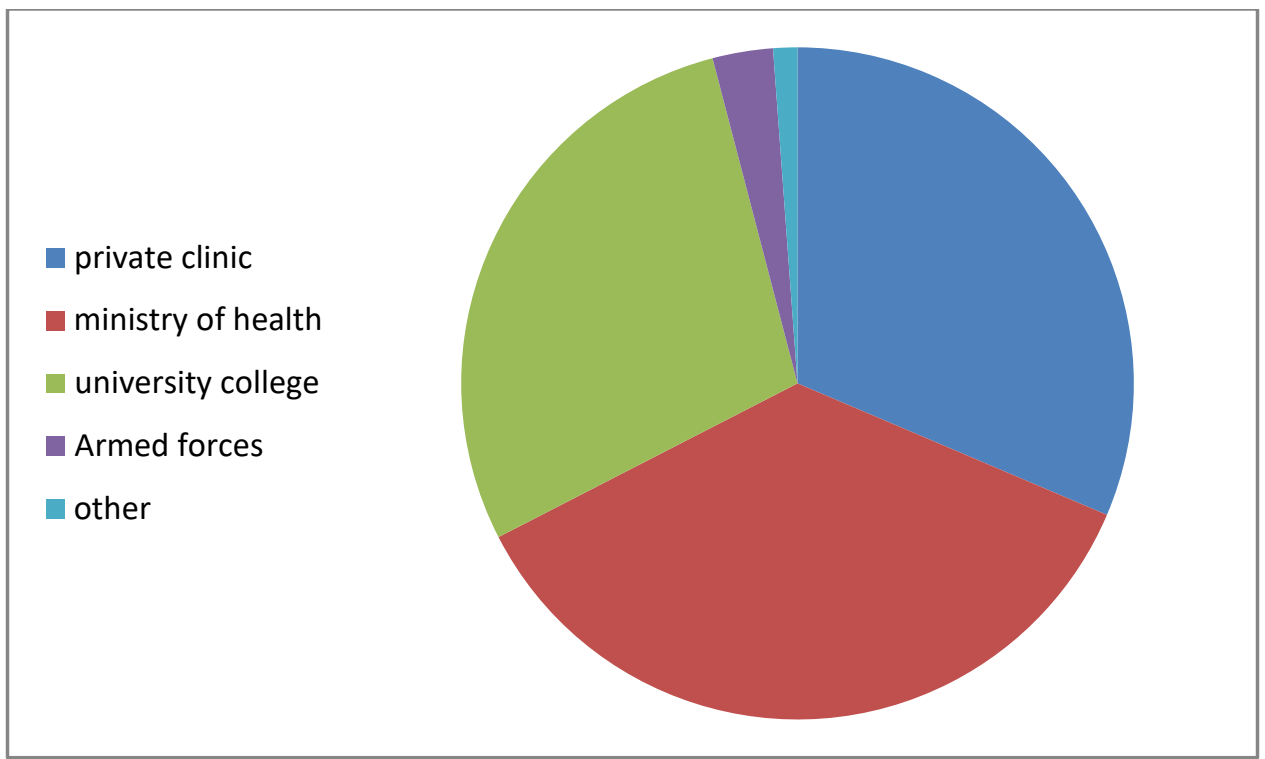

Table 5:- preventive measure.

Figure 2:- Side they are belonging to

\begin{tabular}{|l|l|l|l|l|}
\hline & yes & no \\
\cline { 2 - 5 } & Frequency & Percent & Frequency & Percent \\
\hline Needlestick or sharps injury within the last year. & 107 & 61.5 & 67 & 38.5 \\
\hline $\begin{array}{l}\text { Needlestick or sharps injury, did you report the } \\
\text { incident. }\end{array}$ & 48 & 32.4 & 100 & 67.6 \\
\hline Do you recap the used needles? & 158 & 90.8 & 16 & 9.2 \\
\hline Do you wash your hand in between each patient? & 164 & 94.3 & 10 & 5.7 \\
\hline Total & 174 & 100 & & \\
\hline
\end{tabular}

Table 6:- After injured participants did.

\begin{tabular}{|l|l|l|}
\hline & Frequency & Percent \\
\hline wash the site with water and soap & 48 & 34.8 \\
\hline Wash the site with an antiseptic solution (e.g. Alcohol etc..) & 54 & 39.1 \\
\hline Did nothing & 7 & 5.1 \\
\hline Only squeezed the blood out & 29 & 21 \\
\hline Total & 174 & 100 \\
\hline
\end{tabular}

Table7: The most Technique of recapped used needles

\begin{tabular}{|l|l|l|}
\hline & Frequency & Percent \\
\hline Only a one-handed method & 109 & 62.6 \\
\hline A two handed method & 56 & 32.2 \\
\hline A special mechanical device to recap used needles & 9 & 5.2 \\
\hline Total & 174 & 100 \\
\hline
\end{tabular}

Table 8:- Used needles disposed in.

\begin{tabular}{|l|l|l|}
\hline & Frequency & Percent \\
\hline In the normal refused bin & 20 & 11.5 \\
\hline In a sharps container (safety boxes) & 154 & 88.5 \\
\hline Total & 174 & 100 \\
\hline
\end{tabular}


Table 9:- wearing personal protective equipment.

\begin{tabular}{|l|l|l|l|l|l|l|}
\hline \multirow{2}{*}{$\begin{array}{l}\text { In your practice do } \\
\text { you }\end{array}$} & Always & Sometimes & \multicolumn{2}{l|}{ Do not wear } \\
\cline { 2 - 7 } & Frequency & Percent & Frequency & Percent & Frequency & Percent \\
\hline Wear gloves? & 170 & 97.7 & 4 & 2.3 & 0 & 0 \\
\hline Wear a mask? & 168 & 96.6 & 6 & 3.4 & 0 & 0 \\
\hline $\begin{array}{l}\text { Use protective eye } \\
\text { glasses? }\end{array}$ & 67 & 38.5 & 66 & 37.9 & 41 & 23.6 \\
\hline $\begin{array}{l}\text { Wear gowns, lab } \\
\text { coats? }\end{array}$ & 126 & 72.4 & 23 & 13.2 & 25 & 14.4 \\
\hline
\end{tabular}

Table 11:- Potential routes of blood borne infections

\begin{tabular}{|l|l|l|l|l|l|l|}
\hline $\begin{array}{l}\text { Potential routes of blood-borne } \\
\text { infections in the dental setting may } \\
\text { include which of the following: }\end{array}$ & $\begin{array}{l}\text { Yeq } \\
\text { y }\end{array}$ & & No & \multicolumn{2}{l|}{ Not sure } \\
\hline $\begin{array}{l}\text { Broken skin in contact with saliva } \\
\text { contaminated with blood of HBV- } \\
\text { positive patient }\end{array}$ & 141 & 81 & 4 & 2.3 & 29 \\
\hline $\begin{array}{l}\text { Broken skin in contact with blood of } \\
\text { blood-borne infections positive patient. }\end{array}$ & 147 & 84.5 & 6 & 3.4 & 21 & 16.7 \\
\hline $\begin{array}{l}\text { Broken skin in contact with saliva of } \\
\text { blood borne infections positive patient. }\end{array}$ & 114 & 65.5 & 34 & 19.5 & 26 & 12.1 \\
\hline $\begin{array}{l}\text { Intact skin with blood borne infections } \\
\text { positive patient }\end{array}$ & 45 & 25.9 & 103 & 59.2 & 26 & 14.9 \\
\hline $\begin{array}{l}\text { Intact skin with intact skin of blood- } \\
\text { borne infections positive patient }\end{array}$ & 28 & 16.1 & 101 & 58 & 45 & 25.9 \\
\hline Needle stick injury & 147 & 84.5 & 4 & 2.3 & 23 \\
\hline Aerosol produced by a handpiece. & 83 & 47.7 & 35 & 20.1 & 56 & 13.2 \\
\hline
\end{tabular}

Table 10:- General knowledge of participants about blood borne diseases (HBV, HCV, HIV)

\begin{tabular}{|c|c|c|c|c|c|c|}
\hline & \multicolumn{2}{|l|}{ Yes } & \multicolumn{2}{|l|}{ No } & \multicolumn{2}{|l|}{ Not sure } \\
\hline & $\begin{array}{l}\text { Frequen } \\
\text { cy }\end{array}$ & Percent & $\begin{array}{l}\text { Frequen } \\
\text { cy }\end{array}$ & Percent & $\begin{array}{l}\text { Frequenc } \\
\mathrm{y}\end{array}$ & Percent \\
\hline $\begin{array}{l}\text { Bloodborne infections carrier may look healthy } \\
\text { without showing any symptoms of the disease. }\end{array}$ & 138 & 79.3 & 6 & 3.4 & 30 & 17.2 \\
\hline Blood borne infections can be lethal & 142 & 81.6 & 16 & 9.2 & 16 & 9.2 \\
\hline $\begin{array}{l}\text { Bloodborne infections can be caused by } \\
\text { bacteria }\end{array}$ & 61 & 35.1 & 73 & 42 & 40 & 23 \\
\hline Blood borne infections is contagious & 121 & 69.5 & 30 & 17.2 & 23 & 13.2 \\
\hline Patients can spread the viruses to dentists. & 144 & 82.8 & 13 & 7.5 & 17 & 9.8 \\
\hline HBV vaccination is not for all people & 56 & 32.2 & 87 & 50 & 31 & 17.8 \\
\hline Dentists can spread the viruses to their patients & 132 & 75.9 & 28 & 16.1 & 14 & 8 \\
\hline HBV vaccination does not cause hepatitis & 98 & 56.3 & 46 & 26.4 & 30 & 17.2 \\
\hline HBV vaccination can prevent hepatitis. & 116 & 66.7 & 32 & 18.4 & 26 & 14.9 \\
\hline $\begin{array}{l}\text { HBV vaccination does not increase the risk for } \\
\text { complications. }\end{array}$ & 83 & 47.7 & 58 & 33.3 & 33 & 19 \\
\hline $\begin{array}{l}\text { HBV vaccination is contraindicated in } \\
\text { pregnancy. }\end{array}$ & 60 & 34.5 & 47 & 27 & 67 & 38.5 \\
\hline $\begin{array}{l}\text { The antibodies for HBV need to be checked } \\
\text { after three titers. }\end{array}$ & 94 & 54 & 30 & 17.2 & 50 & 28.7 \\
\hline AIDS is caused by HIV & 132 & 75.9 & 24 & 13.8 & 18 & 10.3 \\
\hline HIV transmitted with sperm. & 110 & 63.2 & 33 & 19 & 31 & 17.8 \\
\hline HIV transmitted with saliva. & 60 & 34.5 & 73 & 42 & 41 & 23.6 \\
\hline $\begin{array}{l}\text { A positive anti-HIV antibody finding indicates } \\
\text { that a patient had contact with the HIV.] }\end{array}$ & 88 & 50.6 & 55 & 31.6 & 31 & 17.8 \\
\hline
\end{tabular}




\begin{tabular}{|l|l|l|l|l|l|l|}
\hline $\begin{array}{l}\text { Reddish, bluish and violet nodules and plaques } \\
\text { found intraorally represent HIV infection: }\end{array}$ & 83 & 47.7 & 48 & 27.6 & 43 & 24.7 \\
\hline $\begin{array}{l}\text { Infection with HCV can cause the liver to stop } \\
\text { working: }\end{array}$ & 104 & 59.8 & 25 & 14.4 & 45 & 25.9 \\
\hline $\begin{array}{l}\text { You can get HCV by getting a blood } \\
\text { transfusion from an infected donor. }\end{array}$ & 125 & 71.8 & 22 & 12.6 & 27 & 15.5 \\
\hline $\begin{array}{l}\text { You can get HCV by shaking hands with } \\
\text { someone who has hepatitis C }\end{array}$ & 35 & 20.1 & 100 & 57.5 & 39 & 22.4 \\
\hline
\end{tabular}

\section{Discussion:-}

This cross-sectional study investigated blood-borne infection among dentists working in El-Madinah ElMunawarah. The frequency of respondents $(61.5 \%)$ had a needle stick or sharps injury within the last year; this is less than that reported in other studies. Khader indicated that $66.5 \%$ of dentists in Jordan were injured by needles [14].

The non-reporting of needle stick injuries in this study was $67.6 \%$. This result is also less than that mentioned by Khader, who found that $77.9 \%$ of all injuries were un-reported by the Jordanian dentists [14].

In the present study, $90.8 \%$ of those surveyed recap needles after use. This figure is higher than a study by Boras conducted in Croatia, which showed that $85 \%$ of the examined dentists do the same [15].

In this study, dentists during practice, wore gloves $97.7 \%$, wore a mask $96.6 \%$, and used protective eyewear $38.5 \%$, and $72.4 \%$ wore gowns, lab coats. In comparison, with the study of Boras [15], only 50\% of the dentists surveyed wore protective gloves, and masks and $43.3 \%$ dentists wore protective eyewear. This means that dentists in ElMadinah El-Munawarah are more careful than their Croatian counterparts in wearing personal protective equipment.

A large percentage of the surveyed dentists $75.9 \%$, said yes that HIV causes AIDS, Only $63.2 \%$ of the surveyed dentists know that HIV is transmitted through sperm. A Positive answer to the question that whether HIV is transmitted via saliva was given by $34.5 \%$ of examined dentist.

Our results are in concordance with Boras [15]. Who found that $37 \%$ of Croatian dentists think that HIV is transmitted through sperm. Moreover, surprisingly, a large percentage of the surveyed Croatian dentists $(60 \%)$ do not know that HIV causes AIDS. $49 \%$ said that HIV is transmitted via saliva.

About the potential routes of blood-borne infections in the dental setting more than $70 \%$ of dentists have the knowledge about the possible routes of bloodborne infection transmission; broken skin in contact with saliva contaminated with blood of blood borne infection positive patient, broken skin in contact with blood of blood borne infection positive patient and needle stick injury had the highest percentage of knowledge.

\section{Conclusion:-}

1. The general incidence of blood borne disease and reporting attitude among dentists found in this survey are of concern.

2. Safer work practices and instrumentation and continued worker education, with particular reared to posttreatment handling of sharp dental instruments and equipment, may reduce occupational blood exposure among dentist.

\section{Recommendations:-}

Health authorities may plan awareness programs and interventions to improve the level of knowledge in those with low level of knowledge about blood-borne disease.

\section{Limitations:-}

There are some potential limitations in this study that should be considered when interpreting the results. First, since the study was a cross-sectional descriptive study, therefore, no direct relationship between variables and outcomes can be proved. A second limitation is the potential reporting bias associated with the self-administered questionnaire with the possibility that dentists tend to over-report compliance Also, to get some participants respond was difficult especially dentists are working in private clinics. 


\section{Acknowledgments:-}

The authors would like to thank the participants for their cooperation in completing the questionnaire and to thank the employees in Ministry of Health for helping with distribution of questionnaires.

\section{References:-}

1. Ayatollahi J, Bahrololoomi R, Ayatollahi F. Vaccination of dentist and other oral health care providers. J Den Med. 2005;18:5-14.

2. Ayatollahi J. Needle-stick injuries in a general hospital: Continuing risk and under reporting. Ann Iranian Med. 2006;3:47-50.

3. Gerberding JL. Occupational exposure to HIV in health care settings. N Engl J Med.2003;348:826-33.

4. Cleveland JL, Barker L, Gooch BF, Beltrami EM, Cardo D. The National Surveillance System for Health Care Workers Group of the Centers for Disease Control and Prevention. Use of HIV post-exposure prophylaxis by dental health personnel: An overview and updated recommendations. J Am Dent Assoc.2002;133:1619-26.

5. Mitsui T, Iwano K, Masuko K. Hepatitis C virus infection in medical personnel after needlestick accidents. Hepatology.1992;16:1109-14.

6. Butt AKnone, Khan AAnone, Khan SYnone, Sharea Inone. Dentistry as a possible route of hepatitis C transmission in Pakistan. Int Dent Jnone. 2003;53:141-4.[PubMed]

7. Updated U.S. Public Health Service. Updated U.S. public health service guidelines for the management of occupational exposures to HBV, HCV and HIV and recommendations for post-exposure prophylaxis. MMWR Recomm Rep. 2001;50:1-52.

8. Cleveland JL, Gooch BF, Lockwood SA. Occupational blood exposures in dentistry: a decade in review. Infect Control Hosp Epidemiol 1997; 18:717-21.

9. Siew C, Chang S, Gruninger S, Verrusio C, Neidle E. Self-reported percutaneous injuries in dentists: implications for HBV, HIV transmission risk. JADA 1992;123:37-44.

10. Siew C, Gruninger SE, Miaw C, Neidle EA. Percutaneous injuries in practicing dentists. JADA1995;126:122734.

11. Sullivan $\mathrm{S}$, et al. Blunt needles for the reduction of needlestick injuries during cesarean delivery: a randomized controlled trial. Obstet Gynecol 2009;114(2 Pt 1):211-6.

12. Faisal-Cury A, Rossi Menezes P, Kahhale S, Zugaib M. A study of the incidence and recognition of surgical glove perforation during obstetric and gynecological procedures. Arch Gynecol Obstet 2004;270:263-4.

13. Tokars JI, Bell DM, Culver DH, et al. Percutaneous injuries during surgical procedures. JAMA1992;267:2899904.

14. Khader Y, Burgan S, Amarin Z. Self-reported needle stick injuries among dentists in North Jordan. East mediterr health J. 2009 Han-Feb;15(1):185-9.

15. Vanja VuEiEeviE-Boras1,Ana CekiE-Arambain1,Ivan Alajbeg1,Dolores BioEina-Lukenda1.Zita BlaaicPotoEki2,Marina OgnjenoviE3. Dentists Knowledge of HIV. Infection. Acta Stomat Croat 2001; 15-18. 